\title{
PIERRE DUBOIS
}

\begin{abstract}
Mme le Professeur Marie-Madeleine Martinet m'a fait l'honneur d'accepter de siéger dans mon jury de thèse (soutenue à Paris-Sorbonne [Paris IV] en 1997), puis d'encadrer mon H.D.R. (soutenue à Paris-Sorbonne [Paris IV] en 2004). Qu'elle en soit chaleureusement remerciée. Ma thèse portait sur "l'orgue dans la société anglaise au XVIII siècle - éthique et esthétique de la modération » (directeur : Professeur Jacques Carré). Dans le cadre de l'hommage collectif que nous rendons aujourd'hui à MarieMadeleine Martinet, il m'a semblé opportun de revenir, presque vingt ans après ce premier travail, comme en une sorte de clin d'œil, sur certains aspects de l'orgue anglais du XVIII siècle, en témoignage de reconnaissance pour les encouragements qu'elle sut me prodiguer pour mes efforts de recherche dans un champ disciplinaire alors quelque peu marginal dans les études anglaises.
\end{abstract}

\section{GENERIC HYBRIDIZATION \\ OF THE ORGAN VOLUNTARY \\ FROM HENRY PURCELL TO WILLIAM RUSSELL}

As is well known, the invention of the organ concerto can be credited to Handel, who introduced this species of composition in his oratorio performances to provide elements of variety and virtuosity. The very format of the English organ voluntary, intended for the church, was subsequently influenced by the Handelian organ concerto, in particular through the adoption of the latter's structure in several movements in place of that in one or two parts that was usual after the Restoration. It may be suggested that a new original form, half-way between religious and theatre music, gradually emerged as the voluntary underwent the influence of the organ concerto, and reciprocally. This configuration can be interpreted as a significant indication of the way religious practice evolved in English society during the late Enlightenment. It may be hypothesized that this transformation and generic hybridization reflected - albeit unconsciously - the contemporary society's aspiration to reconcile entertainment with faith and morality, and the elegant gratification of the senses with religious respectability. The ultimate development of the organ voluntary was arguably attained with the two organ books of William Russell (1777-1813), published respectively in 1804 and 1812, which can be considered as the summit of the genre and 
probably - with those of John Stanley (1736-86) and Samuel Wesley (1766 -1837), his contemporary and friend - as the most accomplished English work for the organ before the advent of Romanticism. After a few remarks on the early development of the voluntary after the Restoration and a brief reminder of the impact of both George Frederick Handel and John Stanley upon the form of the genre, this article will pay attention to the voluntaries of William Russell and conclude with general remarks about the possible social meaning of the exchanges between organ concerto and voluntary.

\section{The Original Forms of the Voluntary.}

After it had been excluded from religious services by the Puritans under the Commonwealth, the organ soon found its place in the liturgy again at the Restoration in 1660. The instruments that had escaped destruction were repaired, new organs were built and, following the lead of Renatus Harris and 'Father' Smith, various organ-builders resumed or took up the trade. If it was used mainly for the accompaniment of psalms and hymns, the organ also played a part in the liturgy as a solo instrument for the performance of an indigenous form of piece called the voluntary. In truth, the voluntary did not have any well-defined structure. In his History of the Science and Practice of Music, Sir John Hawkins likened it to the very free form of the toccata of Italian origin invented by Frescobaldi:

[It] consists in a prompt and ready discussion of some premeditated subject in a quicker succession of notes than is required in the accompaniment of choral harmony. Exercices of this kind on the organ are usually called Toccatas, from the Italian Toccare, to touch; and for want of a better word to express them, they are here in England called Voluntaries. In... [the service of our Church] [they occur] in the morning prayer after the psalms and after the Benediction, or, in other words, between the first and second service; and in the evening service after the psalms. [Hawkins II, 623]

William Mason, precentor of York, underlined the fact that the voluntary could boast no equivalent in other countries and that it could at best be compared to the capriccio:

The species of Music executed upon it in those intervals, when it is permitted to be introduced during ecclesiastical service, is called in 
English a voluntary; and I know of no Italian or French term strictly of the same signification. Capriccio, perhaps, comes nearest. [Mason 304]

In The Compleat Psalmodist, John Arnold defined the voluntary as 'an extempore Air or Prelude played on the Organ immediately after the Reading [of] Psalms' [Arnold n.p. (38)]. As a matter of fact, voluntaries were often improvised by organists, a practice that was often criticized by people who thought that these impromptu attempts were too frivolous or musically inept. However, a whole corpus of voluntaries was composed and published during the eighteenth century and they are the ones that deserve our attention.

The interventions of the organ in church services after the Restoration were clearly stipulated by Edward Lowe in A Short Direction for the Performance of Cathedrall Service (Oxford, 1661) and by James Clifford in The Divine Services and Anthems usually Sung in His Majesties Chappels and all Cathedrals and Collegiate Choirs in England and Ireland etc. (London, 1663). Clifford explained very precisely the order of the liturgy and the moments when a voluntary was to be performed:

\author{
Morning \\ Matins - First Service \\ After the psalms a voluntary upon the organ \\ sung Te Deum and Benedictus \\ first anthem after third collect \\ Litany after the first anthem \\ After the Blessing a voluntary upon the organ \\ Communion service - second service \\ After sermon the second anthem \\ Evening Service \\ After the psalms a voluntary alone by the organ \\ sung Magnificat and Nunc Dimittis \\ first anthem after third collect \\ After sermon the second anthem. [Clifford 43]
}

At Westminster Abbey, the organ was used at the beginning and end of the services [Knight, I, 41]. However, in The Well-Tuned Organ (1660), Joseph Brookbank quoted from a pre-Commonwealth book by Francis Bacon (which Brookbank wrongly said was anonymous), entitled Certain Considerations Touching the Church of England, in which was recommended the performance of a 'middle voluntary' after the reading of the Word of God, in order to introduce a meditative pause 
accompanied by 'some grave sounds' [Bacon 17, quoted in Brookbank 25]. It seems that around the middle of the eighteenth century, it was the norm to play a voluntary as a prelude to the service, another one between the readings and a third one at the end of the service [Swanson 246].

What was its function? In a sermon preached at Tiverton in 1696, the John Newte explained that the voluntary was supposed to 'engage the Congregation to a serious Thoughtfulness' and that it was also 'used at the end of the Psalms, before the Lessons be read, to strike a reverential Awe upon our Spirits, and to melt us into a fit Temper to receive the best Impressions from the Word of God.' [Newte 21]. This conception probably accounts for the origin of the traditional slow irst movement on the Diapasons, the purpose of which is to establish a calm, meditative atmosphere at the beginning of the service or between the readings.

After the Restoration and at the beginning of the eighteenth century, the voluntary generally consisted of a single movement. It is the case of the 33 Verses and Voluntaries by John Blow (1649-1708), which can be considered as the most representative collection of organ pieces of this period [Routh 147]. It is still the case for the voluntaries or fugues (the two terms being used indifferently to designate the same kind of pieces) by Thomas Roseingrave (1690-1766), organist of St. George's, Hanover Square, published by D. Wright around 1734 .

However, voluntaries in two separate movements began to appear from the end of the seventeenth century. An interesting case in point is the Voluntary in $G$ (Z 720) by Henry Purcell (1659-95), which appears therefore as a forerunner of things to come. The two movements were apparently intended to be performed successively as no double bar-line concludes the first section. The fact however that this section ends on the tonic ( $\mathrm{G}$ major) makes a cut possible and one can imagine that the two parts - a very grave initial movement followed by a more lively one - could correspond to, and be performed at, two different moments of the religious ceremony, for instance at the beginning and at the end respectively. Besides, a kind of programme or symbolic intention can be deciphered in the striking contrast between the sombre character of the initial adagio and the faster and merrier fugato that follows. The slow movement on the Diapasons can be interpreted as a penitential lamentation, whereas the second section appears to be an act of praise. These are the two antithetical, yet inseparable, axes of baroque art - a permanent tension between the opposed poles of metaphysical anguish 
and jubilation. They also correspond to the recommendations that can be found in sermons on the use of the organ written after the Restoration and in the course of the eighteenth century. Church music was supposed to perform two contradictory, yet complementary, functions at the same time: both establish an atmosphere of peace in order to 'infuse into [men] ... a grave, sedate, and sober Mediocrity,' but also 'change our unruly Passions into more exalted Extacies of heavenly Joy' [Banner 19]. Men's affections must be both 'composed' (if too agitated) and 'enlivened' (if too sluggish) [see Dubois 2007 (2), passim].

Purcell's short voluntary in G can be viewed as a deliberate answer to such a two-pronged demand. Although this piece is a minor work among Purcell's overall output, its first section is deeply moving. It is written in the durezze e ligature ('dissonances and ties') style inspired by Frescobaldi's toccatas that contemporary English organists admired and endeavoured to emulate [Holman 100]. It consists in one long phrase that tries to rise as in a painful ascension towards light finally to fall back down in a gesture of renunciation or some avowal of failure. In spite of its key of G major, the piece is sombre and pessimistic in tone. With its subtle harmonies, the constant interplay between major and minor modes and its relentless drive, this slow movement is one of the most moving Diapason pieces in the whole organ repertory of the seventeenth and eighteenth centuries. By contrast, the short fugato that follows (twenty-odd measures in all) seems to be a kind of playful about-turn or, depending on how one sees and plays it, a disenchanted and falsely good-humoured conclusion.

The thirteen voluntaries by William Croft (1678-1727) - who, like Purcell, was John Blow's pupil, whom he succeeded at Westminster from 1708 - can be divided into those with a single movement (voluntaries Nos. 4, 5, 6, 7, 8, 9, 13) and those in two. In the latter, the only indication of a disruption between the two sections is sometimes a simple tempo indication (faster) but without the first part having a proper conclusion (voluntaries Nos. 1 and 2). In other instances, the two sections are separated by a double bar-line (voluntaries Nos. 3, 10, 11, 12). This structure was to impose itself in the course of the eighteenth century, in particular due to the influence of Maurice Greene (16951755), whose twelve voluntaries (Ed. 112) are all in two movements. This binary form has sometimes been compared to that of the German prelude and fugue [see for instance Routh 210] but this does not seem really convincing as the second movement is not systematically a fugue 
and English fugues were not composed in the rigorous manner of German ones anyway.

\section{From Handel's Organ Concertos to John Stanley's Voluntaries.}

John Stanley (Fig. 1), a remarkable virtuoso on the organ in spite of his blindness from infancy, was organist of the Inner Temple, Master of the King's Band of Musicians after William Boyce and director of the oratorio performances at Drury Lane after Handel.

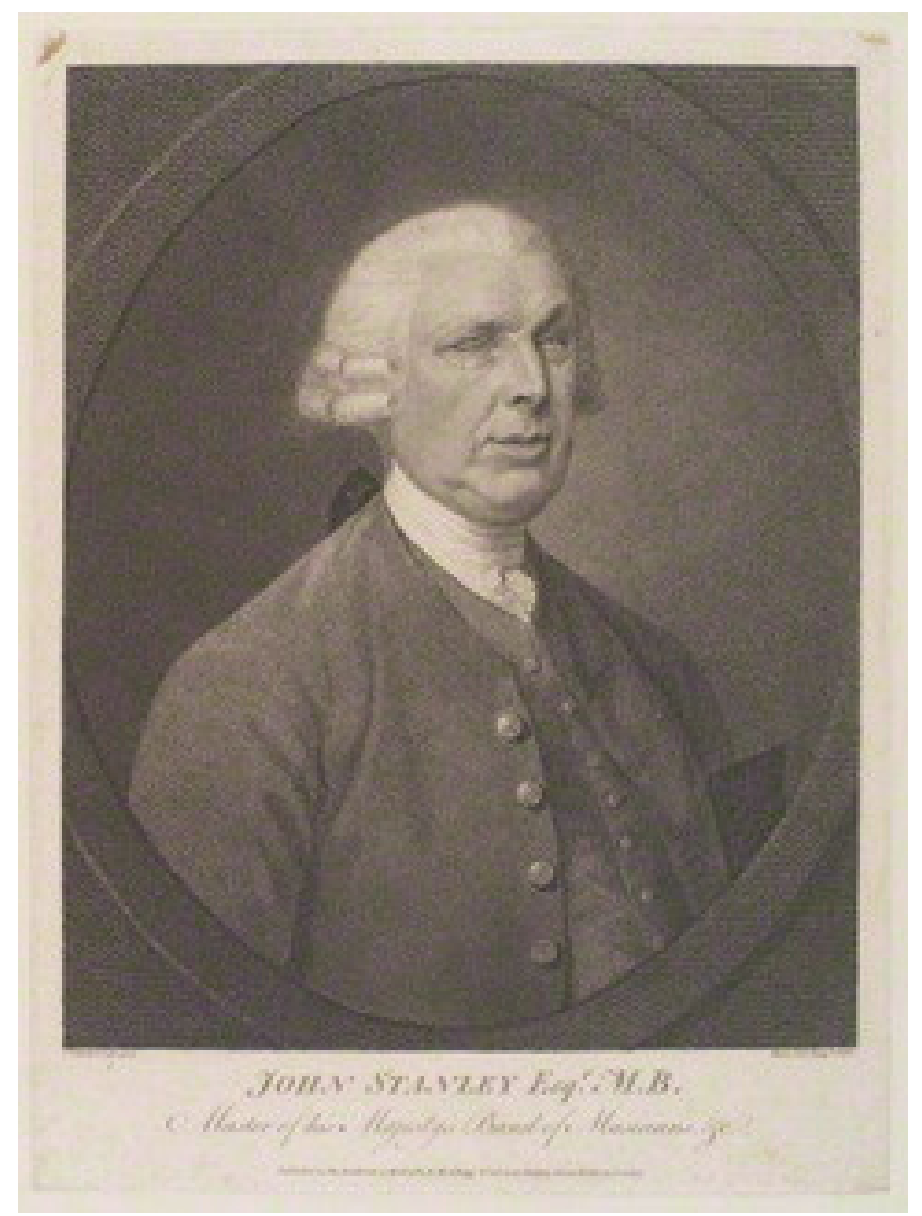

Fig. 1. Thomas Gainsborough, after Mary Ann Rigg (née Scott), Portrait of John Stanley (1781), stipple engraving, NPG D14076 (C) National Portrait Gallery, London 
With him the voluntary acquired a new structure. Even though in most of his voluntaries (op. 5, 6 and 7, published successively between 1748 and 1754) he still resorted to the two-section structure adopted by his master Maurice Greene and his contemporaries (John Travers, Handel himself, William Boyce, etc.), he was directly inspired by the model provided by Handel's organ concertos, as he composed voluntaries in three or four movements (No. 8 op. 5 , No. 5 op. 6 , and No. 8 op. 7 are in three movements, whereas No. 1 op. 5 and No. 6 op. 6 are in four movements). It is only a small proportion of the whole (5 out of 30) but this structural innovation testifies to the influence of concerto culture upon the church organ repertory. Like Handel before him, Stanley would play organ concertos during oratorio performances in Lent and appears to have done so on no fewer than 165 occasions (79 at Covent Garden and 86 at Drury Lane) [William 94]. He also composed concertos himself, so the genre had obviously no secret for him.

Of course, the organ concerto did not have any liturgical role as its primary function was to show off the composer's invention and the performer's digital virtuosity. However, oratorios were seen as a supplement to the liturgy, since their main raison d'être was to contribute to the moralization of the lyrical scene during Lent (Handel is famously reported to have retorted to Lord Kinnoull at the first public performance of Messiah that he would be sorry if he only entertained the audience and wished instead to make them better [recounted by James Beattie in 1780, quoted in Dean 140]). As Peter Lynan remarks [Lynan I, 46], the insistence of several writers (such as Charles Avison, William Mason or John Hawkins) on the contemplative quality of the slow improvised introduction on the Diapasons such as Handel would play, legitimized the profane concerto genre as an adjunct to the spiritual meaning of the oratorio between the parts of which the concerto would be performed. For William Mason, for instance, Handel's intention in erecting an organ upon the theatre stage was 'undoubtedly to difference as much by its dignified form, as by its solemn tones, that semi-dramatic species of composition the Oratorio from a genuine Opera' [Mason 72-3]. Reciprocally, aspects of the voluntary, intended for religious services, had an influence on the way Handel himself would improvise the preludes to his concertos as is shown by Hawkins's often-quoted description:

As to his performance on the organ, the powers of speech are so limited, that it is almost a vain attempt to describe it otherwise than by its effects. A fine and delicate touch, a Volant finger, and a ready

Palette pour Marie-Madeleine Martinet (2016) 
delivery of passages the most difficult, are the praise of inferior artists: they were not noticed in Handel, whose excellencies were of a far superior kind; and his amazing command of the instrument, the fullness of his harmony, the grandeur and dignity of his style, the copiousness of his imagination, and the fertility of his invention were qualities that absorbed every inferior attainment. When he gave a concerto, his method in general was to introduce it with a voluntary movement on the diapasons, which stole on the ear in a slow and solemn progression; the harmony close wrought, and as full as could possibly be expressed; the passages concatenated with stupendous art, the whole at the same time being perfectly intelligible, and carrying the appearance of great simplicity. This kind of prelude was succeeded by the concerto itself, which he executed with a degree of spirit and firmness that no one ever pretended to equal. [Hawkins II, 912]

Although it was sometimes thought that Handel's organ concertos were 'not the true organ style' [Bingley II, 146], the use of the very word 'voluntary' by Hawkins to qualify the slow prelude on the Diapasons leaves one in no doubt: Hawkins linked Handel's practice to the solemnity and majesty of the slow movement that introduced most church voluntaries. The two genres - voluntary and concerto - thus began to exchange some of their characteristics and modalities. While it was thought fit to evoke the church instrument and its noble and grave character on the theatre stage, it was reciprocally deemed appropriate to import elements of diversity and seduction from the lighter concerto genre into the church.

Unlike organ concertos, Stanley's voluntaries were composed with the clear intention of fulfilling a liturgical role [Williams 112]. As mentioned above, the organ would intervene on three distinct occasions: at the beginning of the service, between the psalms and the first reading, and at the end of the service. The opening voluntary generally consisted of a slow introduction on the Diapasons $(63.3 \%$ of Stanley's introductory movements are to be played on the Diapasons, and 33.3\% on the Full Organ), followed by an allegro on a solo stop (Cornet or Flute). The closing voluntary was generally a largo followed by a fugue, while the middle voluntary was generally a short improvised piece. Stanley's various voluntaries can easily be put within these functional categories. However, those which adopt a concerto structure in three or four movements raise the question of their integration within the liturgy. Were the various movements to be performed successively, without interruption, as a concerto in the concert-room? Or was it the practice to split up the voluntary into several sections and play each of these

Palette pour Marie-Madeleine Martinet (2016) 
separately at distinct moments of the religious celebration? Jonas Blewitt (1757-1805) suggests in the title of one of his organ books (1797) that this was an acceptable practice: Twelve easy and familiar movements for the organ: which may be used either seperately or in continuation so as to form one compleat voluntary [Blewitt]. However, it may be worth remarking that at both St. Andrew's and the Inner Temple, the two churches where Stanley was organist, there was no choir [Williams 23] and this may have prompted the composer to extend the size and duration of his voluntaries so as to give the organ a more important role in the absence of sufficient choral forces. It was reported that numerous London organists - including Handel - would flock to the churches where Stanley was due to play in order to listen to him at the end of the service [letter to The Universal Magazine, July 1786, quoted in Williams 22; Bingley II, 206]. It may therefore be surmised that he would perform the closing voluntary very much in the style of an organ concerto so he could display all the art of which he was capable. A newspaper reported:

GOING to Church may indeed be reckoned among our Sunday amusements, as it is made a mere matter of diversion among many well-meaning people, who are induced to appear in a place of worship from the same motives that they frequent other public places. To some it answers all the purposes of a route or assembly, - to see and be seen by their acquaintance; and from their bows, nods, curt'sies, and loud conversations one might conclude that they imagined themselves in a drawing-room. To others it affords the cheap opportunity of shewing their taste for dress: not a few, I believe, are drawn together in our cathedrals and larger churches by the influence of the music more than the prayers, and are kept awake by a jig from the organ-loft, tho' they [are] lulled to sleep by the harangue from the pulpit. A well-disposed Christian will go a mile from his own house to the Temple-Church, not because a Sherlock is to preach, but to hear a Solo from Stanley. [Connoisseur 154-5]

The exchange between musical practices on the stage and in church seems therefore to have worked both ways: while the organ provided an element of religiosity to the concert and lent a degree of solemnity to the oratorio performance [Dubois 2005, 95; Lynan I, 42], the religious service tended to transform itself, partly at least, into a real concert, which did not please everybody, of course. In the satirical mode that was used so frequently in the periodical press of the period, the anonymous author of the article quoted above concludes his remarks by advising the abolition of Christianity and the substitution of opera airs,

Palette pour Marie-Madeleine Martinet (2016) 
songs and catches for Sternhold and Hopkins's metric psalms, in order better to entertain the company [Connoisseur 155]!

A significant clue of the exchanges between the secular sphere of the concerto and the religious one of the voluntary is the inclusion of the Siciliana in the latter. A traditional slow dance to a $6 / 8$ or $12 / 8$ beat, it is characterized by the rhythmic figuration $\curvearrowright \rho \delta$ which endows it with a pastoral character. In the eighteenth century, the Siciliana was frequently used in opera and in slow concerto movements. Its soft rhythm and the fact that it was often treated in the minor mode contributed to its appeal in expressing melancholy emotions and feelings. Handel notably composed an alla siciliana movement in his organ concerto in F No. 5, op. 4. Now interestingly, in spite of the fact that it was considered rustic or even of vulgar origin [Monelle 30], one can observe that the Siciliana made its way into the voluntary. John Stanley resorted to this figuration for the first movement of his voluntary No. 1 op. 6; William Walond in his voluntary No. 3 of his third book; Jonas Blewitt in his voluntary No. 3, op. 4; William Russell in his voluntaries No. 4 and 7 of the first book and No. 7 of the second, etc.

In his book on church music, William Mason endorsed the shift from the serious fugue to less complex forms, the primary mission of the voluntary being to establish a context of calm and serenity:

It may here be observed, that what the modern Composers have in a great measure rejected, the more antient were so fond of, that even their partizans at present, will hardly admit a Chorus or a Concerto to be a grand one, in which a Fugue does not constitute the principal movement. Yet since the introduction of Air, I am apt to think that a mode of Voluntary might be pursued of much less elaborate contexture than this, which would much more perfectly answer our assigned purpose. Prompt, and, as it were, casual strains, which do not fix the attention of the hearer, provided they are the produce of an original fancy which scorns to debase itself by imitating common and trivial melodies, are, of all others, the best adapted to induce mental serenity. We in some sort listen to such Music, as we do to the pleasing murmur of a neighbouring brook, the whisper of the passing breeze, or the distant warblings of the lark or nightingale. [Mason III, 312]

This led Mason to justify the use of the siciliana, despite its association with profane music, provided it were performed with taste: 'The Siciliana movement is also of a very rhythmical kind; yet, when executed with taste and tenderness, comes under the denomination of 
Simple Music, and may most fitly be adapted to ecclesiastical purposes.' [Mason III, 314]

It is not surprising, therefore, that one should find other popular forms, in particular numerous 'marches', 'gavottes', or such indications as 'spiritoso' and 'gratioso' (Russell, voluntary No. 1, Book 1, voluntary No. 3 and 5, Book 2), and even the mention 'alla Pollaca' (that is to say on the rhythm of a Polish dance, which was very much in favour in the early nineteenth century) for a Cornet movement (Russell, voluntary No. 3, Book 1). The influence of profane music intended for the concert-hall opened up new prospects in the field of the voluntary.

Another aspect of Stanley's voluntaries that seems to have originated in the organ concerto is the way he tended, in his Cornet allegros, to oppose two sharply contrasted sound planes as if the organ alone was to imitate the dialogue between the band and the solo instrument in the concerto (or for that matter, that between tutti and ripieno, to use the terms of the Italian concerto grosso tradition stamped by Corelli). What is interesting in such cases is that the 'solo' part, which is longer than the tutti section devolved to the Cornet on the Great, is to be played on the Eccho, that is, the softest division of the instrument. While the initial exposition of the theme and the final recapitulation are given over to the Cornet (as they would be to the full band in a concerto), the development and variations, which run for a much greater number of bars than the tutti, is therefore played on a softer division that sounds distant and as it were set back. It is exactly as if the point was to evoke the concerto in which the solo instrument is less powerful than the orchestral tutti. A quick count of the number of bars devolved to each part is quite revealing: in the last movement of voluntary No. 2, op. 6 , there are 39 bars on the Cornet against 42 on the Eccho; in No. 3, op. 6, 44 bars on the Cornet against 68 on the Eccho; in No. 1, op. 7, 28 bars on the Cornet against 45 on the Eccho, etc. The 'small' manual is therefore promoted to the rank of principal - which can be seen as one of the many indices of the quest for moderation and restraint that defined the English eighteenth-century organ, the passages played piano outnumbering those played forte.

\section{The Rise of a Mixed Genre.}

The shift of the voluntary towards the concerto, or, if one prefers, its gradual transformation under the influence of the concerto, is part of a more general popularization of the latter genre (of Italian origin) in 
England in the second half of the eighteenth century. The phenomenon was a European one but it took various ways in different countries. In England, while the Corellian model imposed itself for the violin and strings, it was of course the Handelian model that had a considerable influence for the organ concerto. In a slightly emphatic way, Dr. Charles Burney went as far as to write that 'public players on keyed-instruments, as well as private, totally subsisted on these concertos for near thirty years' [Burney II, 825n]. Generally edited on 2 staves so as to render their execution more accessible and easier for amateur musicians [Lynan I, 66, 69], keyboard concertos were often performed in a domestic environment (as illustrated in Jane Austen's Pride and Prejudice, for instance), and this was facilitated by the presence of harpsichords and pianofortes, but also of chamber organs, in numerous aristocratic and upper-class residences. In the second half of the eighteenth century, the galant style enabled the diffusion of the concerto genre among amateurs thanks to its relative technical simplicity and the 'very predictability of the various formulas associated with the style' [Lynan I, 185].

The organ concerto was so popular (there remain above 200 such compositions by English composers) that it became one of the main features of the concerts given in the pleasure gardens such as Ranelagh, Vauxhall and Marylebone. Music played a double role in the pleasure gardens: of course, it provided sheer entertainment and sensual gratification; but it was also meant to contribute to the social harmony of the place [see Dubois 2007 (1), 56-9]. The presence of an organ in the concert-room or rotunda of a pleasure garden was framed by this double imperative: it was intended to provide pleasant entertainment but also, by association of ideas with the church instrument, to endow the place with an aura of respectability, as contemporary advertisements did not fail to stress. An overture on the organ was generally played as a prelude to the concert, and the organ was used both for the accompaniment of singers in extracts from oratorios and for the performance of organ concertos composed specifically for the pleasure gardens. These gardens 'functioned as surrogates for the theatres and concert rooms during the summer months, and there were, therefore, clear links with the programmes mounted at each' [Lynan I, 60]. Peter Lynan further remarks that one of the striking aspects of these organ concertos was their insularity [Lynan I, 60]: the genre was the preserve of English organists, whereas concert rooms welcomed numerous foreign artists and in particular fortepianists such as Dussek, Clementi and Cramer, 
who were reluctant to perform in the pleasure gardens. This confirms that, mainly owing to Handel's influence, the organ had acquired a special status as a vehicle for the expression of patriotic feelings in the collective psyche [see Dubois 1997, passim]. It also accounts for the fact that the organ concerto could also, in return, influence the voluntary, as the two genres were clearly identified with the English national taste, character and culture. Both were also remarkable for their relative technical simplicity, compared with the keyboard concertos of foreign virtuosos reviled by a Charles Dibdin [Dibdin 10]. Simplicity, moderation and the absence of ostentation were considered as qualities proper to good English taste, while gratuitous virtuosity was criticized [see D'Arcy Wood passim ; McVeigh, passim] and considered to be the most condemnable of the foibles of foreign artists, whether castrati or instrumentalists (even if they did exert a real fascination on the theatre audiences).

In this ambiguous tangle, in which references to sacred music intermixed with borrowings from easy galant music, the organ concerto was bound to undergo an evolution that could not fail to influence the voluntary in return. A significant illustration of the exchanges between the two genres can be found in the compositions of James Hook (17461827) (Fig. 2), who was to be the organist of Marylebone gardens, then Vauxhall gardens (from 1774 to 1820), and composed over 2,000 songs for these gardens (among which the famous Lass of Richmond Hill) but also operas, an oratorio (The Ascension) that was performed at Vauxhall, numerous concertos for the organ, the pianoforte and the clarinet, sonatas and a method for the pianoforte, and also a book of 10 voluntaries for the organ (Op. 146). Required to perform an organ concerto every evening from May to September at Vauxhall, Hook sought above all to please the public of the garden by composing in the then 'modern' galant idiom, and the influence J.C. Bach (and also Mozart) can be perceived in his works [Ward Russell I, 312]. In his Memoirs, oboist William Parke wrote of Hook's music: 'The music ... displayed an appropriate variety of style and much fine melody. If it was not always original, it was always pleasing, and therefore much applauded' [Parke II, 6]. Simplicity and melodic grace were the necessary qualities to charm the gardens' English audience.

Palette pour Marie-Madeleine Martinet (2016) 


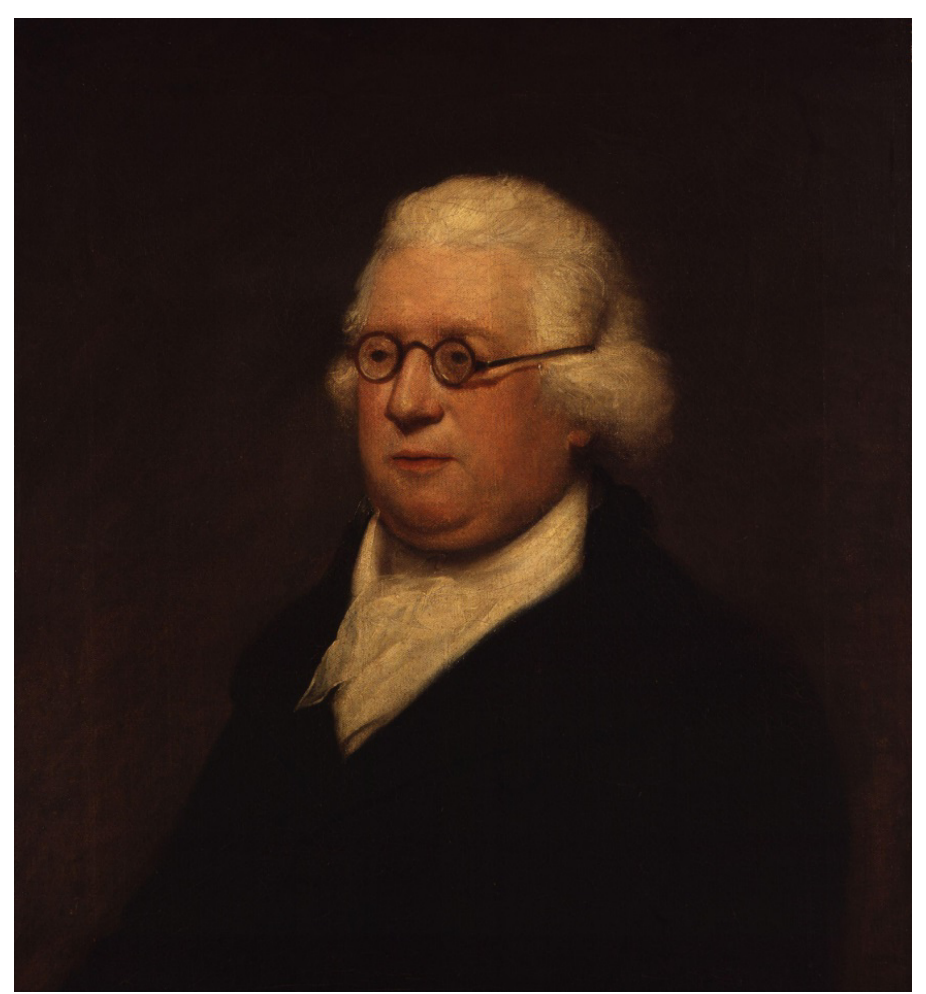

Fig. 2. Lemuel Francis Abbott (1760-1802), Portrait of James Hook, ca. 1800. NPG 2519 (C) National Portrait Gallery, London.

What is striking, stylistically speaking, is the resemblance between Hook's concertos and his own voluntaries. In the latter, he did indeed follow the convention of the slow movement on the diapasons, often written in hymn-like, slow-moving chords, in the place of the initial allegro that was usual in a concerto, yet the galant melodic inspiration was the same. With Hook, who was organist of Saint John's, Horselydown, Bermondsey for a long time, 'light,' pleasing music was undoubtedly making its way into the church. His voluntaries (in two or three movements like his concertos) are nothing less than miniature concertos for a single instrument and they could easily have been performed in place of these - and reciprocally. 


\section{William Russell and the Organ Voluntary}

The organist of St. Ann's Church, Limehouse, from 1798 and of the Foundling Hospital from 1801 until his death, William Russell was considered to be one of the best keyboard players of his time [Bingley II, 284]. He composed four odes and two oratorios, as well as Scottish songs and an interesting organ concerto (1810), the very expressive central larghetto of which (with obligato pedal part) testifies to the influence of Mozart. Well aware of the developments in organ building (his father Hugh was an organ builder), he followed closely the stylistic evolutions of his time and held Mozart and Haydn in high esteem. He even borrowed the theme of the final chorus, Per adisi Gloria, of Haydn's Stabat Mater as the subject for the fugue of his voluntary No. 10 of the $2^{\text {nd }}$ book, duly mentioning his debt (Fig. 3):

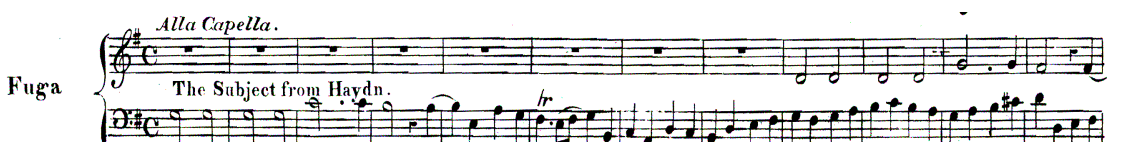

Fig. 3. William Russell, Twelve Voluntaries for the Organ or Pianoforte, II (1812), exposition of the fugue from voluntary No. 10, with the mention of Haydn.

Russell somehow enriched the national genre of the organ voluntary by bringing in constituents of the classical style while remaining faithful to the tradition. Like his friend Samuel Wesley's - but without his extravagance - Russell's style was mixed [see Ward Russell I, 363], and it can be said that he pretty well embodied the ideal of the fusion of the 'ancient' and 'modern' styles that John Marsh advocated in an essay published in the Monthly Magazine in 1796 [Marsh passim].

An interesting feature of Russell's works is their compositional ambition and sheer scale. While most English organ concertos in the eighteenth century lasted around a dozen minutes, Russell's lasts twice as long in performance [Ward Russell I, 362]. Similarly, his voluntaries are striking for their length and magnitude, and not only with respect to the number of movements, since we have seen that the multiplication of movements had started with Stanley. Russell's voluntaries are generally in two movements, sometimes three (Book I, No. 11; Book II, Nos 1, 3, 5, 6), four (Book I, Nos. 1, 7, 8), and up to five (Book I, No. 12). Yet it is mainly his ability to extend and develop the musical discourse that is remarkable. Whereas Stanley's voluntaries rarely last more than five 
minutes in performance, none of Russell's can be executed in less than four minutes and some last above ten minutes, that is the average length in time of an organ concerto of the period. Some of Russell's fugues exceed in breadth, length and technical demand (without ever being gratuitously showy) all that was commonly composed by English composers for the organ at the time. Some are more than 200 bars long (see for instance Book I, No. 12 and Book II, No. 10), that is, double the average length of Stanley's fugues. Such an ambition to excel in contrapuntal development may be due to the growing influence of J.S. Bach's '48' (as Das Wohltemperierte Klavier, BWV 846-893, was then called), revealed in England by Samuel Wesley notably. The theme of the fugue that concludes Russell's Concerto in G is similar to that of the Fugue in E Major from Book Two of J.S. Bach's Wohltemperierte Klavier [see Ward Russell I, 357]. Besides, Russell also extended and developed his slow or moderate movements much more than was usual for organ voluntaries (see for instance the $2^{\text {nd }}$ movement, allegretto, of voluntary No. 15, Book II, written as a dialogue between Cremona and Hautboy with obbligato pedal, which is some 180 bars long).

Contrary to the common eighteenth-century practice, Russell was also the first composer to indicate specifically the use of pedals, which were only just then beginning to be introduced in England. Thirteen out of his twenty-four voluntaries bear a clear mention of a pedal part, which also contributes to the amplification of the sound effect.

Foreshadowing Felix Mendelssohn's organ sonatas (which, must it be repeated, had originally been commissioned to the German composer by the London publishers Coventry and Hollier in 1844), Russell's voluntaries borrowed their discursive dimension from the organ concerto and became therefore concert pieces in all but name. Their performance in the context of a religious service implied that the organist enjoyed a rather considerable amount of time, which must incidentally have been the case at the Foundling Hospital where Russell officiated: it is known that Handel's performances of Messiah attracted huge crowds (for one of his early performances in 1751, it is reported that 'there were above 500 coaches, besides chairs, $\& c$., and the tickets amounted to above 700 guineas' [Gentleman's Magazine, May 1751, quoted in Boeringer II, 262]) and a picture of the chapel at the beginning of the nineteenth century (when Russell was organist there) shows the great number of choir children on the organ gallery and people in the pews, suggesting that any service with such large attendance would have lasted quite a long time (see Fig. 4).

Palette pour Marie-Madeleine Martinet (2016) 


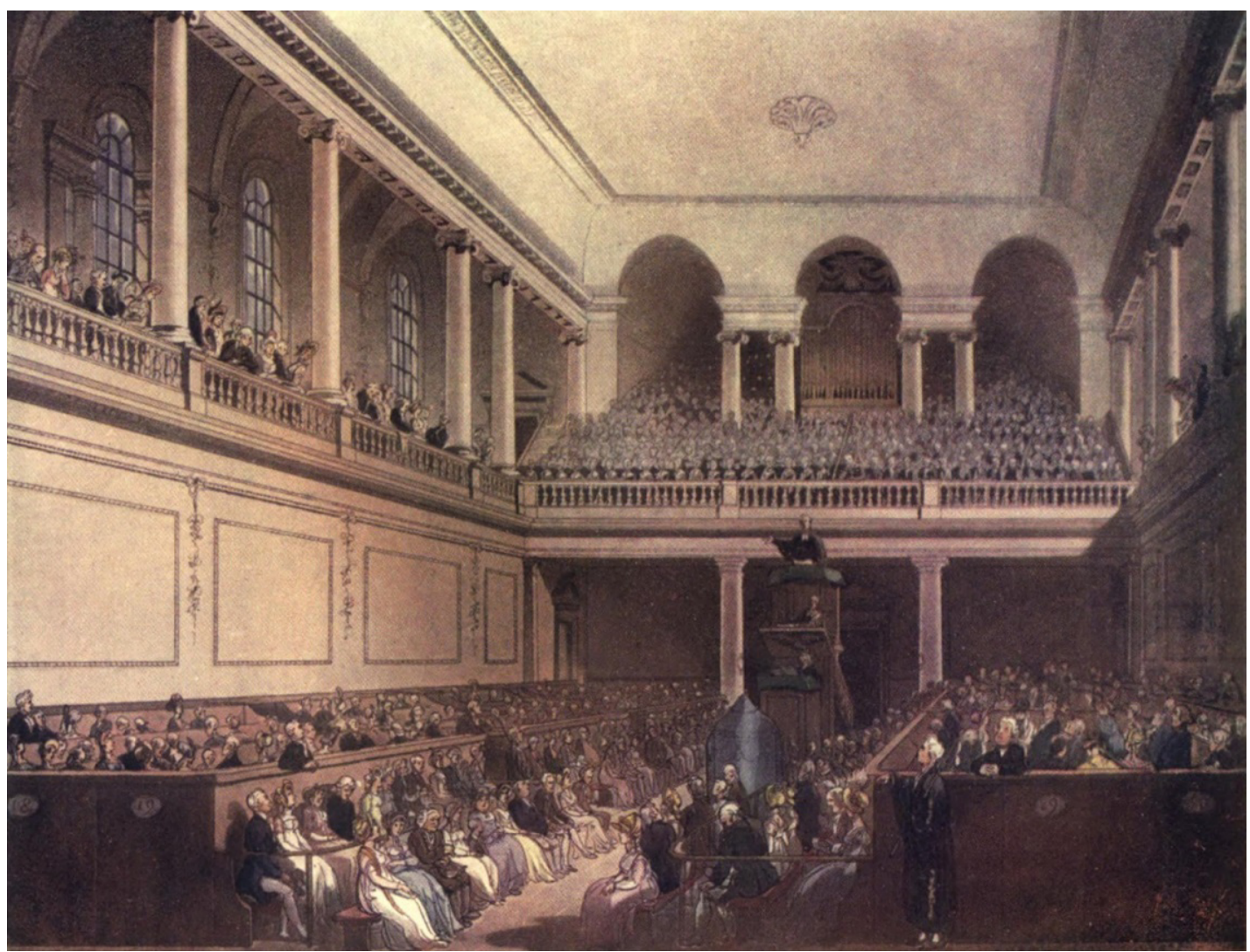

Fig. 4: Thomas Rowlandson and Augustus Charles Pugin, The Foundling Hospital Chapel, in Ackermann's Microcosm of London (1809), plate 37.

The fact that in Russell's more developed voluntaries the first and third movements generally end on the dominant rather than the tonic clearly indicates that the following movement should follow immediately so as to resolve the harmonic suspension thus created. The writing itself implies that the whole voluntary should be performed uninterruptedly. With Russell the voluntary definitely acquired a new musical dimension as a developed piece of music the raison d'etre of which existed outside the mere confines of its liturgical function and required a continuous performance like a concert piece.

This does not mean, however, that Russell's intention was not sincerely religious, and everything suggests that he had the highest idea of his role as a Church organist. The presence of numerous fugues in his 
voluntaries is a clue to his quest for a noble and serious form compatible with the sacred role of the organ, as the fugue was then considered to be the religious and sublime musical form par excellence. William Crotch held it in high esteem as one of the "most interesting of all kinds of movement:'

If a fugue be a barbarous invention, unworthy of an ingenious composer, let it be omitted altogether. But I should rather say, it is one of the most interesting of all kinds of movement, resembling the discourse of a great orator, who, having chosen his theme, states it clearly; examines it in all its bearings; views it through all its changes and varieties of aspect; and, in conclusion, by recapitulating the whole, stamps his argument strongly on the mind. [Crotch, 101; voir aussi 33]

Russell even ended his organ concerto with a fugue, as mentioned before, and this probably underscores his intention to compose a 'serious' organ concerto - as opposed to the lighter pieces in the same genre composed for the pleasure gardens - and thereby assert the link between its character and that of the church voluntary.

Another clue to Russell's wish to maintain the religious tone of the voluntary is the way he would often conclude a light or animated movement with a few slow bars played piano on the Diapasons in order to restore the calm and dignity deemed proper in the place of worship (see for instance the end of voluntaries Nos. 3, 4 and 5 of Book 1, and No. 2 and 4 of Book 2 - see fig. 5). The same practice can also be found in several instances in the works of John Bennett (c. 1735-84) and Jonas Blewitt (1757-1805), for instance.

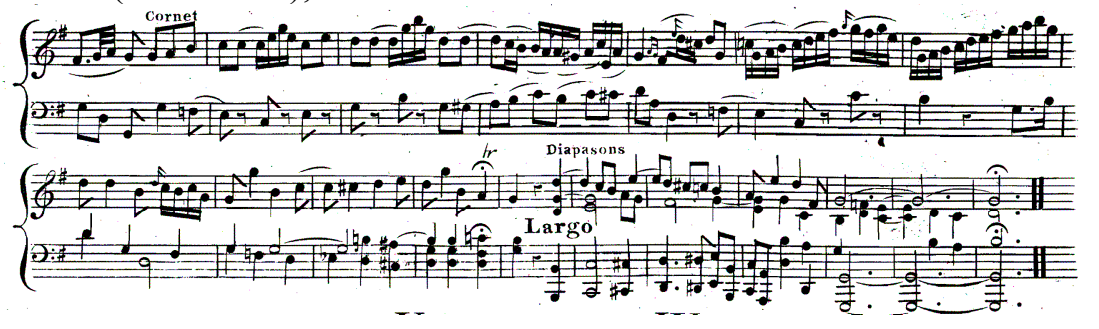

Fig. 5. William Russell, Twelve Voluntaries for the Organ or Pianoforte, I (c.1804), p. 10 , end of $2^{\text {nd }}$ movement of Voluntary No. 3.

What Russell's music illustrates, then, is an attempt to fuse together the two national genres: if the voluntary itself is specifically English and traditionally associated with the Church of England, the organ concerto is a national invention too and the exchanges between them were after all quite natural. The two genres enriched each other reciprocally: while 
the concerto leaned on the religious aura of the voluntary, so to speak, in order to impose itself on the concert stage, the voluntary borrowed structural elements and a new magnitude from the concerto.

\section{Religion, Entertainment and Decorum.}

The exchanges between voluntary and concerto described above testify to a particularly interesting collusion, or confusion, between the religious and the profane spheres since the 2 genres originally belonged to two distinct public spaces and performed different roles. This marriage may be interpreted as a sign of the growing secularization of English society at the advent of the industrial era. Even before the beginning of the nineteenth century the intrusion in church music of a 'light' and 'airy' character inherited from profane music had been denounced. It was notably the case of Sir John Hawkins who in his History of Music criticized the Cornet Voluntary made popular by Maurice Greene:

Notwithstanding that he was an excellent organist, and not only perfectly understood the nature of the instrument, but was great master of fugue he affected in his voluntaries that kind of practice on single stops the cornet and the vox humana for instance, which puts the instrument almost on a level with the harpsichord; a voluntary of this kind being in fact little more than a solo for a single instrument, with the accompaniment of a bass; and in this view Greene may be looked on as the father of modern organists. This kind of performance, as it is calculated to catch the ears of the vulgar who are even more delighted with melody or what is called air, than harmony, was beneath one, whose abilities were such that Mattheson, a man little disposed to flattery and who was himself one of the first organists in Europe, has not scrupled to rank him among the best of his time. [Hawkins II, 884]

Such discourse is of course not 'musicological' but infused with ideological overtones: Hawkins contrasts two parameters of musical composition - harmony and melody - and asserts the superiority of the former over the latter, considered capable of pleasing only the 'vulgar.' Harmonic and polyphonic writing as well as the science of fugue are raised up to the apex of stylistic hierarchy and church music must consequently conform to such requirement. The fugue had acquired its special status as the religious form par excellence, as mentioned above, for ideological reasons. In terms of such criteria of judgment, it is easy to understand that the galant style that developed in particular in the music composed for the pleasure gardens from the second half of the 
eighteenth century - including organ concertos - could not be approved by the zealots of a grave and serious conception of religious music. The influence of this style upon the voluntary was perceived by some as a form of decadence and an index of the transformation of the place of worship into a substitute for the theatre stage or music rotunda dedicated to entertainment music.

Some of the English organists of the second half of the eighteenth century actually asserted their intention to differentiate themselves from the secular style. It was the case, notably, of John Keeble (c. 17111786), the organist of St. George's, Hanover Square, London, where he had succeeded Roseingrave. In the 'preface' reproduced at the beginning of each of his 3 books of 'pieces' for the organ (which he did not call 'voluntaries'), he wrote:

The obligato style of writing, which consists of fugues, inversions, canons, double-descants, and the like, is interwoven in many parts of these compositions [...]. This style of writing, so proper for the church, has of late been much neglected by the young professors, from an opinion of its dryness, want of wit, and destroying the true and original spirit of genius. How far I have succeeded in removing these objections, by the freedom of modulation, is now submitted to the public; whose approbation will be a sufficient motive to publish others of the same sort. [Keeble I, Preface, 1]

If, like Stanley, Keeble sometimes composed voluntaries in more than two movements, in the manner of concertos, he remained extremely sparing with indications of registration: he frequently mentioned the Diapasons, sometimes the Cornet or the Trumpet but most of his twenty-four pieces are devoid of registrations. The sound colour, and in particular the orchestral tone so dear to Stanley or Russell, mattered less to Keeble than the contrapuntal science of his compositions. He thus appears rather conservative in spite of some bold modulations that look forward to those of Wesley, and in his compositions he seems to have wanted to react directly against what he may have perceived as a kind of decadence of the 'pure' style of organ music for the church. Keeble is however a bit of an exception.

Another, very different interpretation of the phenomenon of the reciprocal influence of voluntary and organ concerto can however be suggested. As Michael Giffin has remarked, the interpretations concerning the reality of faith in the Georgian period have tended to vary greatly and to be coloured and 'regarded in either a positive or 
negative light depending on the stance of the historian' [Giffin 1]. In his seminal study of 1934, Church and State in England in the Eighteenth Century, Norman Sykes began to rehabilitate the Georgian Church [Walsh and Taylor 2]. Sykes remarked that, while hostile critics of the eighteenth-century Church of England talked of a process of 'secularisation of the Church,' it might be more appropriate to use the phrase 'laicisation of religion' [Sykes 379] as the laity performed an active, vigorous role within the Church. 'The eighteenth century,' Sykes explained, 'was not wholly unresponsive to the nobler impulses of the spirit, nor neglectful of the cultivation of the arts. It was an era fecund in musical composition, especially in church music, and in the practice of campanology' [Sykes 425]. The numerous organ voluntaries composed during the period under study testify indeed to the intense musical activity that took place within the Church of England. But, as Conrad L. Donakowski rightly remarks, "for the average citizen, public meetings, songs, festivals, and religious liturgies provided a theatre for a new way of life' [Donakowski 'Preface' n.p. (i)]. It can be suggested that the opening up of religious music, in particular the organ voluntary, to the outside influence of theatre and concert music, may not have been the consequence of the secularization of society but rather that of a broadening of the audiences, for 'the new social and economic conditions dictated that culture could no longer remain the sport of an isolated elite' [Donakowski 4]. On the eve of the Romantic period, music and religion were still closely inter-related, even though 'religion' is to be understood less in 'a strictly ecclesiastical sense, but in the sense of a set of primary symbols which harmonize diverse experiences' [Donakowski 308].

Russell's voluntaries (and those of his contemporaries), influenced as they were by the input of the secular organ concerto, may then arguably be said to express in aesthetic terms the new cultural part the Church was playing in Georgian society. As Jonathan Barry has shown, the organ 'remained the centre, as it were, of the musical world' [Barry 194]. While secular music-making in the gardens relied on the aura of the organ and its association with the oratorio and the figure of Handel 'as a symbol of cultural respectability, reassuring the public of the Christian as well as moral function of music as a task surely performed by the close ties with local Anglican church life' [Barry 198], the reverse was true as the Church played a cultural role by broadening its appeal through the legitimation of new cultural activity. Jonathan Barry explains: 
Cultural provision was still heavily dependent on the Church, as well as vice versa. Both in practical terms and in the Church's support was important, not least because of a long-lasting distrust of a totally commercial culture controlled by market forces alone. This interdependence lies at the heart of understanding eighteenth-century England as neither a confessional state where the established Church could afford to ignore voluntary support, nor a secular consumer society without any use for an established Church, but rather as a commercial society with genuine religious pluralism, that is with a genuine pluralism based on genuine religious allegiances. The Church of England weathered its crisis to emerge secure but altered in such conditions. [Barry 208]

It may then be argued that the music of Russell, especially, and that of other composers of the same period, somehow reflected the state of the relationship between Church and society and that it was a fit expression of the conception of religion that prevailed at the time, a conception that was strongly marked by the joyful outlook of Latitudinarianism as opposed to that of the Puritans, separatists or dissenters, as George Coningesby explained in a sermon:

What seems to have given many of our Separatists their greatest Distaste of this Ceremony, is the sour Moroseness, and melancholy Severity of Temper, that diffuses its Leaven into all their Actions, and indisposes them to every thing that looks like Joy. This makes them dress Religion, the most Chearful thing in the World, in nothing but Sackcloth and Ashes; and imagine a Joyful Countenance inconsistent with the Gravity of a Christian. [Coningesby 20-1]

Latitudinarianism, which may have been a state of mind more than a theological position, or 'a temper rather than a creed' [Gerald Cragg quoted in Walsh and Taylor 36], was less a set of belief than a practical philosophy of moderation and tolerance. Yet, as Walsh and Taylor remark, 'a commitment to the principle of religious moderation did not necessarily mean a commitment to amiable passivity' and 'it would be a grave error to see Latitudinarian Anglicanism as merely a stage in the onward march of secularization' [Walsh and Taylor 42]. Although Latitudinarian Churchmen were a minority, their influence on the Church of England at large was great and, rather than undermine the foundations of revealed religion, they contributed to the strengthening of the cohesion of the Church of England and buttressed its sense of security and identity [see Walsh and Taylor 43, 53, 57-8].

It is against this background that the place and meaning of the organ voluntary as it developed in the latter part of the Georgian period, and in 
particular the voluntaries composed by William Russell, can be best understood. This music was no longer penitential and 'grave' (unlike Purcell's Voluntary in $G$ discussed above). It offered instead a positive, optimistic, even sunny vision of religion. These voluntaries are energetic, dynamic and good-humoured. Their role was to impart a strong dose of positive energy and to contribute to the establishment of a kind of peaceful and serene confidence. The Church of England endeavoured to reconcile the moral with the spiritual and the demands of social harmony with those of religion. Music played a distinctive role in this perspective: beyond the mere sensual gratification it could provide, it was supposed to have a positive effect on men and aesthetic pleasure was thus endowed with an ethical dimension. As early as the end of the seventeenth century, Bishop Francis Atterbury had explained that harmony had a potent effect on the passions and that it could 'guide and elevate [them] towards their proper Object,' namely religion [Atterbury 231-2]. A little later, Richard Banner explained for his part that music could curb excesses and bring tranquillity:

Are our Minds then enraged with Passion, and transported with heat, It [Music] can infuse into them such a grave, sedate, and sober Mediocrity, as not only to allay those exhorbitant sallies, but to change our unruly Passions into more exalted Extacies of heavenly Joy. [Banner 19]

Music was thought to have a real 'efficacy' as it could act upon men's dispositions and humours. Its goal was to contribute to the edification of the believers and to prepare them favourably towards devotion, as John Topham explained in a sermon published in 1824:

In regard to the general conducting of religious worship, the rule laid down by the apostle is simply this, that 'every thing be done with decency;' which may be interpreted - introduce no rite - attach no ceremony; - use no instrument in the service of religion, but what leads to edification -is a soother of the passions - or is an help to devotion. And whatever has a tendency to such desirable results - whatever raises the thoughts of man to a more sublime conception of his being; whatever elevates his affections, and mollifies his temper, and mellows his feelings; whatever allures his thoughts from this world and its affections and lusts - whatever so calms the troubled stream of life, and induces a kindred calmness to breathe through the veins of man, and for a time lulls every unkind and sinful emotion into repose; whatever has this power must be congenial to the spirit of religion. And that the melody of music possesses this enchanting charm, who that has a breast to feel or an ear to hear can deny? [Topham 8]

Palette pour Marie-Madeleine Martinet (2016) 
Topham insists here on the reforming capability of music: it can both elevate the believers morally and pacify them thanks to its 'enchanting charm.' The imperative of moderation applies to religious matters and, in broader cultural terms, it contributes to the harmony of social relations [see Dubois 2007 (2), 46].

The extension of the form of the voluntary under the influence of the organ concerto and the reciprocal borrowings of the two genres one from the other may thus be interpreted as a visible sign of the symbiosis between two social and cultural spheres that were not as radically opposed or incompatible as might be thought. The paradoxical, quasi oxymoronic expression of 'sacred entertainment' that had been used to describe Handel's Messiah on its first performance in Dublin in 1741 covers in fact a deliberate cultural project of reconciliation between the demands of religion and a conception of social harmony that remained central until the first decades of the nineteenth century. Polite Georgian society bound together refinement, decorum and sociability and, unlike the Victorians, saw no contradiction between the charming grace of light melody and pleasing music, and their conception of religion. There were, of course, objections, as we have seen, and numerous writers castigated 'airy' music and the immorality of the stage, but what the evolution of the voluntary teaches us is that the organ, which presided musically over church services, oratorio performances and pleasure gardens concerts alike, brought these different rituals under a similar banner, so to speak, and asserted that the imperatives of moderation, good taste and joyfulness had to prevail in both concert venues and church services. Russell's voluntaries and his organ concerto encapsulate this optimistic outlook and present a remarkable generic and stylistic synthesis that is essentially English - a striking parting shot for a (double) national genre before the advent or Romanticism.

Pierre DuBOIS

Université François Rabelais (Tours)

Palette pour Marie-Madeleine Martinet (2016) 


\section{BIBLIOGRAPHY}

\section{PRIMARY SoURCES}

AnOn. The Connoisseur, By Mr. Town, Critic and Censor-General (London, Thursday, 25 July 1754).

ARNOLD, John. The Compleat Psalmodist, or the Organist's, ParishClerk's and Psalm-Singer's Companion (London, Robert Brown, $5^{\text {th }}$ ed., 1761).

ATTERBURY, Francis. The Usefulness of Church-Musick, a Sermon preached on St.Cecilia's Day in the Year 1698 (London, 1736).

BACON, Francis. Certain Considerations Touching the Better Pacification and Edification of the Church of England (London, 1640), re-ed as Certain Considerations for the Better Establishment of the Church of England (London, 1689).

BANNER, Richard. The Use and Antiquity of Musick in the Services of God (Oxford, 1737).

BINGLEY, William. Musical Biography; or, Memoirs of the Lives and Writings of the Most Eminent Musical Composers and Writers, who have flourished in the Different Countries of Europe during the Last Three Centuries (London, Henry Colburn, 1814), 2 vols.

BLEWITT, Jonas. Twelve easy and familiar movements for the organ: which may be used either seperately or in continuation so as to form one compleat voluntary (London: Printed for the author \& sold at Messrs. Culliford, Rolfe, \& Barrows, 1797).

BROOKBANK, Joseph. The Well-tuned Organ, or, an Exercitation; wherein, this Question is fully and largely discussed, Whether or no Instrumental, and Organical Musick be lawful in Holy Publick Assemblies? (London, 1660).

BuRnEY, Charles. A General History of Music from the Earliest Ages to the Present Period, London,1776-89 (re-ed. New-York, Dover Publications, 2 vols, 1957).

CLIFFORD, James. The Divine Services and Anthems usually Sung in His Majesties Chappels and all Cathedrals and Collegiate Choirs in England and Ireland etc. (London, 1663).

CONINGESBY, George. Church Music Vindicated; and the Causes of its Dislikes Enquired into (London, 1733).

CROTCH, William. Substance of several Courses of Lectures on Music read in the University of Oxford and the Metropolis (London, Longman, Rees, Orme, Brown \& Green, 1831). 
DiBDIN, Charles. A Letter on Musical Education (London, 1791).

HAWKINS, John. A General History of the Science and Practice of Music (London, 1776), ré-éd. (London, Novello, 1875), 2 vols.

KeEBle, John. 'Preface,' Select Pieces for the Organ (London, 1777), 3 vols, 1-2.

MARSH, John. "A Comparison between the Ancient and Modern Styles of Music," The Monthly Magazine, Vol. II, London, 1796.

MASON, William. Essays, Historical and Critical, on English Church Music (York, 1795) re-ed. in The Works of William Mason (London T. Cadell and W. Davies, 1811), 4 vols.

NEWTE, John. The Lawfulness and Use of Organs in the Christian Church, asserted in a Sermon preach'd at Tiverton in the County of Devon Upon the $13^{\text {th }}$ of September 1696, on Occasion of an Organ being erected in that Parish-Church (London, 1701), $2^{\text {nd }}$ ed.

PARKE, William. Musical Memoirs: Comprising an Account of the General State of Music in England, from the first Commemoration of Handel in the Year 1784, to the Year 1830 (London Henry Colburn and Richard Bentley, 1830), 2 vols.

TOPHAM, John. A Sermon, in which is attempted to be shewn, how far the Use of Music is allowable or serviceable, in religious Exercises (London G. \& W.B.Whittaker, 1824).

\section{SECONDARY SOURCES}

BARRY, Jonathan. 'Cultural Patronage and the Anglican crisis: Bristol, c. 1689-1775,' in Walsh, John, Colin Haydon and Stephen Taylor, The Church of England, c.1689-c.1833: from Toleration to Tractarianism (Cambridge, Cambridge U P, 1993), 191-208.

BOERINGER, James. Organa Britannica: Organs in Great Britain 16601860 (Lewisburg,, Bucknell U.P. 1986), 3 vols.

D'ARCY WoOD, Gillen. Romanticism and Music Culture in Britain, 1779-1840 - Virtue and Virtuosity (Cambridge, Cambridge U.P., 2010).

DEAN, Winton. Handel's Dramatic Oratorios and Masques (London, Oxford U.P., 1959).

DonaKowsKi, Conrad L. A Muse for the Masses: Ritual and Music in an Age of Democratic Revolution, 1770-1870 (Chicago, U of Chicago P, 1977). 
DUBOIS, Pierre. «L'orgue et la société : identité et changements de rôles en Angleterre au XVIII ${ }^{\text {ème }}$ siècle ", L'homme et la société, $\mathrm{n}^{\circ} 126$ (Paris, L'Harmattan, 1997/4), 19-35.

—. "L'oratorio en Angleterre au XVIIIè siècle : théâtralisation du sacré, sacralisation du théâtre ", in Musique et théâtralité dans les Îles Britanniques, eds. Claire Bardelmann et Pierre Degott (Metz, C.E.T. de l'université Paul Verlaine, 2005), 91-110.

-. "Resorts of Ambiguity: the Eighteenth-century Pleasure Gardens, a 'bewitching Assemblage of Provocatives"', in Les Usages du temps libre, ed. Emmanual Roudaut, Revue Française de Civilisation Britannique (Paris, CRECIB, vol. XIV, $\mathrm{n}^{\circ} 2$, 2007), 53-66.

-. "The Organ and its Music Vindicated" - a Study of "Music Sermons" in Eighteenth-century England' The B.I.O.S. Journal, n³1 (Oxford, Positif Press, 2007), 40-64.

GIFFIN, Michael. Jane Austen and Religion: Salvation and Society in Georgian England. (Gordonsville, VA, USA Palgrave Macmillan, 2002. ProQuest Library Web accessed 27 October 2015).

Holman, Peter. Henry Purcell (Oxford, Oxford U.P., 1994).

-. "Samuel Wesley as an Antiquarian Composer", in Music and the Wesleys, ed. Nicholas Temperley and Stephen Banfield (Urbana, Chicago andSpringfield, U of Illinois P, 2010), 183-99.

KNIGHT, David Stanley. 'The organs of Westminster Abbey and their music, 1240-1908', Ph.D., Historical Musicology (King's College, University of London, 2001.

LYNAN, Peter. "The English Keyboard Concerto in the Eighteenth Century," D. Phil. Thesis, (University of Oxford, 1997).

MCVeIGH, Simon. Concert Life in London from Mozart to Haydn (Cambridge, Cambridge U.P., 1993).

Monelle, Raymond. The Sense of Music: Semiotic Essays (Princeton, Princeton U P, 1947/2000).

RouTH, Francis. Early English Organ Music from the Middle-Ages to 1837 (New York, Barnes \& Noble, 1973).

SWANSON, Jean Phyllis. 'The Use of the Organ in the Church of England (1660-1800)', Ph.D. Phil., (University of Minesota, 1969).

SYKES, Norman. Church and State in England in the Eighteenth Century (Cambridge, Cambridge U P, 1934).

WALSH, John, Colin Haydon and Stephen Taylor, The Church of England, c.1689-c.1833: from toleration to Tractarianism (Cambridge, Cambridge U P, 1993). 
WARD RUSSELL, Gillian. 'William Russell (1777-1813): An Inquiry into his Musical Style [...],' Ph.D. Phil. (University of Leicester 1994) 4 vols.

WiLliams, A. Glyn. 'The Life and Works of John Stanley (1712-86),' Ph. D. Phil., (University of Reading, 1977). 